\title{
Gambaran Pelaksanaan Indikator Mutu Syariah Perawat di Rumah Sakit Islam Yogyakarta PDHI
}

\author{
Arlina Dhian Sulistyowati ${ }^{1}$, Sri Handayani², Kasih Nursanti ${ }^{3}$ \\ 1,2 Stikes Muhammadiyah Klaten \\ ${ }^{3}$ Rumah Sakit Islam Yogyakarta PDHI
}

\begin{tabular}{|c|c|}
\hline Article Info & Abstract \\
\hline $\begin{array}{l}\text { Article History: } \\
\text { Accepted April 13rd } 2019 \\
\text { Key words: } \\
\text { Sharia Quality Indicator; } \\
\text { Nurse; Spiritual }\end{array}$ & $\begin{array}{l}\text { Sharia is the standard quality indicators in Islamic hospitals consisting of } \\
\text { indicators of minimum service standard (SPM) Quality Indicators and the } \\
\text { compulsory Islamic Sharia. Indicators of the quality of the Sharia has a } \\
\text { purpose in an effort to standardize the measurement and documentation of } \\
\text { application of Islamic values in the service of the patient. Indicators Quality } \\
\text { Syariah consists of } 8 \text { quality indicators Sharia SPM which consist of reading } \\
\text { basmalah in administering drugs and action, hijab mandatory training for } \\
\text { patients, for patients, educational fqih Islami, ECG examination according to } \\
\text { gender, the wearing of a hijab nursing mothers, the wearing of hijab in the } \\
\text { operating room and scheduling operations outside of prayer time. } \\
\text { Indicators of the quality of the sharia is another indicator of the quality of } \\
\text { compulsory Shariah which consists of mentoring talqin patients breathe } \\
\text { death, reminiscent of the time of prayers and the installation of appropriate } \\
\text { gender DC. This research aims to know the description of the } \\
\text { implementation of the Sharia quality indicators conducted by nurses in } \\
\text { inpatient PDHI Yogyakarta Islamic hospital which reflects the } \\
\text { implementation of spiritual services to the patient. This research uses } \\
\text { descriptive quantitative research design. The population in this study are } \\
\text { all the nurses in inpatient care. The respondents of the research as much as } \\
63 \text { respondents obtained with the Total Sampling techniques by observing } \\
\text { the exclusion criteria in research. Instrument research using } \\
\text { questionnaires. Analysis of univariate data by using a percentage. The } \\
\text { results showed of } 63 \text { respondents, a total of } 6.3 \% \text { of the respondents the } \\
\text { implementation of Sharia in the category quality indicators are lacking, } \\
38.1 \% \text { of respondents in the category is good enough and as much as } 55 \text {, } \\
6 \% \text { in the category either. The conclusion that can be drawn from this } \\
\text { study is the implementation of a quality indicator of the Sharia Islamic in } \\
\text { PDHI Yogyakarta Hospital in the category of good. }\end{array}$ \\
\hline
\end{tabular}

\section{PENDAHULUAN}

Rumah sakit adalah tempat menyediakan dan memberikan pelayanan kesehatan yang meliputi berbagai masalah kesehatan.
Indonesia sebagai salah satu negara dengan mayoritas penduduk muslim terbesar di dunia senantiasa berupaya agar setiap sendi kehidupannya diatur dalam bingkai keislaman. Rumah sakit dituntut

Corresponding author:

Arlina Dhian Sulistyowati

arlinadhian@gmail.com

Jurnal Kepemimpinan dan Manajemen Keperawatan, Vol 2 No 1, May 2019

DOI: http://dx.doi.org/10.32584/jkmk.v2i1.214

e-ISSN 2621-5047 
mempunyai tanggung jawab yang lebih, tidak hanya dalam pelayanan kesehatan namun juga upaya penjagaan nilai-nilai islam dalam pelaksanaannya (Hafid, 2016).

Rumah sakit syariah adalah rumah sakit yang dalam pengelolaannya mendasarkan pada maqhashid syariah (tujuan diadakannya syariah) yaitu penjagaan agama, jiwa keturunan, akal dan penjagaan harta (Dewan Syariah Nasional, 2016). Rumah sakit syariah dilaksanakan berpedoman pada Fatwa Dewan Syariah Nasional Majelis Ulama Indonesia (Mukisi, 2017). Empat karakter utama dalam pelayanan yang islami yaitu rabbaniyah, akhlaqiyah, waqi'iyah dan insaniyah. Pembeda pelayanan kesehatan islami dan pelayanan kesehatan non islam terletak pada karakteristik rabbaniyah yaitu keyakinan dan penyerahan segala sesuatu karena kehendak Allah SWT. Rumah sakit islam sebagai tempat yang menawarkan pelayanan jasa dengan menerapkan dan mengembangkan pelayananan berdasarkan prinsip syariah (Sunawi, 2012).

Keberadaan rumah sakit syariah dalam pelaksanaannya memberikan jaminan operasional rumah sakit dan dilaksanakan sesuai syariah baik dalam pengelolaan manajemen maupun pelayanan pasien yang berfungsi untuk meningkatkan kualitas pelayanan, dan sarana dakwah islam di rumah sakit. Keberadaan rumah sakit syariah tidak hanya mementingkan keuntungan semata namun juga memperhatikan kegiatan keagamaan dengan memperhatikan kualitas karyawan maupun pasien dalam beribadah kepada Allah (Mustiana, 2014). Rumah sakit islam mempunyai dua fungsi utama yaitu fungsi bisnis dan fungsi sosial. Fungsi bisnis dijalankan dengan manajemen professional dan fungsi sosial sebagai salah satu upaya dalam menolong kaum dhu'afa (Sjarqiah, 2015).

Rumah sakit syariah dalam pelaksanaaannya untuk peningkatan mutu pelayanan berpedoman pada Standar dan
Instrumen Sertifikasi Rumah Sakit Syariah. Standar Sertifikasi Rumah Sakit Syariah terdiri dari 5 bab yang merupakan rincian dari Maqashid Syariah yaitu panjagaan agama (Hifz al-din), penjagaan jiwa (Hifz alnafs), penjagaan akal (Hifz al-'aql), penjagaan keturunan (Hifz al-nash) dan penjagaan harta (Hifz al-mal), dimana pada masing-masing bab dibagi menjadi dua kelompok standar yaitu kelompok manajemen syariah dan kelompok pelayanan syariah (Solihudin, 2012).

Manajemen syariah merupakan manajemen yang disesuaikan dengan syariah islam dimana sangat mempengaruhi pelayanan jasa yang diberikan kepada konsumen (Sumadi, 2017). Rumah sakit syariah mencantumkan sistem manajemen pada Standar Kelompok Manajemen Syariah yang meliputi 6 standar salah satunya adalah Standar Syariah Manajemen Mutu (SSMM). Manajemen mutu merupakan sistem manajemen yang berfokus pada kualitas dengan tujuan terciptanya kepuasan pelanggan dengan melibatkan seluruh anggota organisasi. Mutu merupakan sistem manajemen yang berfokus pada orang/karyawan dan bertujuan untuk terus menerus meningkatkan nilai yang diberikan pada pelanggan (Mulyadi, 2013).

Mutu rumah sakit akan tercapai dengan perencanaan dan wawasan yang baik melalui penetapan standar yang diukur dengan indikator. Standar Syariah Manajemen Mutu memuat tentang pemeliharaan aqidah, ibadah, akhlak dan muamalah melalui aktivitas keagamaan dan tercantum pada indikator mutu syariah (Mukisi, 2017). Indikator mutu syariah merupakan standar yang ada dalam rumah sakit syariah yang terdiri dari Standar Pelayanan Minimal dan Indikator Mutu Wajib Syariah. Peranan medis sangat penting dalam manajemen mutu pelayanan rumah sakit. Indikator ini mempunyai tujuan diantaranya adalah sebagai upaya standarisasi pengukuran dan pendokumentasian dari penerapan nilanilai syariah dalam pelayanan pasien. Ruang 
lingkup pelaksanaan indikator syariah ini membutuhkan adanya kompetensi Sumber Daya Insani dalam membimbing, mendidik, dan mengajak pasien untuk melaksanakan ibadah selama menjalani pemeriksaan dan pengobatan di rumah sakit. Indikator SPM (Standar Pelayanan Minimal) memuat 8 hal diantaranya terdapat mandatory training untuk fiqih pasien dimana pelaksanaannya melibatkan seluruh karyawan terutama perawat. Pihak yang berperan dalam pelaksanaan indikator mutu Syariah berdasarkan profil indikator mutu adalah perawat (Mukisi, 2017)

Dampak dari pelaksanaan indikator mutu Syariah antara lain peningkatan pelayanan kesehatan, peningkatan kinerja dan kepuasan perawat serta meningkatnya kepuasan pasien. Pelaksanaan indikator mutu Syariah yang baik akan meningkatkan kualitas pelayanan Rumah Sakit. Kualitas pelayanan ini akan membuat hubungan yang harmonis antara penyedia barang dan jasa dengan pelanggan sehingga dapat memberikan dasar yang baik terciptanya loyalitas pelanggan dan membentuk suatu rekomendasi dari mulut ke mulut yang menguntungkan bagi penyedia jasa tersebut (Nursalam, 2015).

Penelitian yang dilakukan Fuad (2017) mengungkapkan bahwa Rumah Sakit Umum Daerah Meuraxa Kota Banda Aceh telah menerapkan prinsip islami dalam pelayanannya dengan mengaplikasikan empat indikator yaitu ikhlas, lemah lembut (Latifah), kasih sayang (mawaddah), dan amanah. Penelitian tersebut juga menunjukkan adanya hubungan pelayanan islami dengan kepuasan pasien. Sejalan dengan penelitian yang dilakukan Sumadi (2017) yang menyatakan adanya pengaruh yang signifikan antara penerapan manajemen Syariah di Rumah Sakit Islam Surakarta dengan kepuasan konsumen. Faktor yang mempengaruhi kepuasan konsumen dalam penelitian tersebut antara lain adalah kualitas pelayanan, persepsi harga dan fasilitas yang disediakan oleh rumah sakit. Sejalan dengan penelitian
Sunawi (2012) menyatakan faktor yang mempengaruhi pelaksanaan indikator mutu antara lain perilaku petugas, pembiayaan pengobatan, pengelolaan data pasien dan lingkungan fisik. Semua aspek tersebut dapat menjadi faktor dalam pelaksanaan indikator mutu.

Rumah Sakit Islam Yogyakarta PDHI adalah salah satu rumah sakit swasta di Daerah Istimewa Yogyakarta yang sudah tersertifikasi sebagai Rumah Sakit Syariah oleh DSN-MUI yang memberikan pelayanan kesehatan berbasis agama Islam. Rumah Sakit ini merupakan Rumah Sakit Tipe C dengan visinya yaitu terwujudnya rumah sakit yang berkualitas, modern, handal dan kebanggaan umat serta Islami, dengan misinya yaitu menyelenggarakan pelayanan kesehatan yang cepat, akurat, profesional, terakreditasi, mengedepankan kepuasan pelanggan dan peduli kepada kaum dhu'afa dengan Motto yaitu karena Allah kami sajikan yang terbaik untuk kesembuhan anda. Menjadi Rumah Sakit Syariah maka Rumah Sakit Islam Yogyakarta PDHI berupaya untuk melayani pasien dengan pelayanan yang islami dengan mengedepankan kepuasan pasien. Pelayanan Kesehatan Islami merupakan segala bentuk pengelolaan kegiatan asuhan medik dan asuhan keperawatan yang dibingkai dengan kaidah-kaidah Islam (Lamsudin, 2012). Berdasarkan hal-hal diatas maka peneliti ingin mengetahui lebih lanjut bagaimana gambaran pelaksanaan indikator mutu syariah oleh perawat di Rumah Sakit Islam Yogyakarta PDHI.

\section{METODE}

Metode penelitian yang digunakan adalah deskriptif kuantitatif. Penelitian ini bertujuan untuk memperoleh informasi mendalam tentang pelaksanaan indikator mutu Syariah di Rumah Sakit Islam Yogyakarta PDHI. Populasi dalam penelitian ini adalah seluruh perawat yang berada di rawat inap di Rumah Sakit Islam Yogyakarta PDHI. Pengambilan data dilakukan pada bulan Desember 2018 sampai Januari 2019. 
Populasi pada penelitian ini berjumlah 82 perawat. Pengambilan sampel pada penelitian ini yaitu total sampling dengan kriteria eksklusi sebagai berikut :

1. Perawat yang sedang cuti

2. Perawat yang sedang sakit

3. Perawat baru/ sedang dalam masa orientasi

\section{Perawat rawat inap}

Sampel pada penelitian ini berjumlah 63 perawat. Penelitian ini menggunakan analisa univariat. Pada penelitian ini peneliti menjelaskan tentang jalannya penelitian dan menjunjung tinggi etika penelitian yang meliputi respect for human dignity, respect for privacy and confidentiality, respect for justice inclusiveness and balancing harm and benefits). Kuesioner penelitian dibuat sendiri oleh peneliti sejumlah 18 butir pertanyataan favourable dan un favourable dengan menggunakan penilaian Skala Likert (1-4). Kuesioner serta telah dilakukan uji validitas $(>0,444)$ dan reliabilitas $(0,943)$.

\section{HASIL}

\section{Karakteristik Responden}

Gambaran karakteristik responden perawat rawat inap di Rumah Sakit Islam Yogyakarta PDHI adalah sebagai berikut :

Tabel 1

Karakteristik Responden di Rumah Sakit Islam Yogyakarta PDHI

\begin{tabular}{clcc}
\hline No & \multicolumn{1}{c}{ Indikator } & f & $\%$ \\
\hline 1 & Jenis Kelamin & & \\
& a. Laki-laki & 13 & 20,6 \\
& Perempuan & 50 & 79,4 \\
\hline 2 & Umur & & \\
& a. $17-25$ tahun & 20 & 31,7 \\
& b. $26-35$ tahun & 39 & 61,9 \\
& c. $36-45$ tahun & 4 & 6,3 \\
\hline 3 & Lama Kerja & & \\
& a. $1-5$ tahun & 51 & 81 \\
& b. $6-10$ tahun & 10 & 15,9 \\
& $11-15$ tahun & 1 & 1,6 \\
& $6-20$ tahun & 1 & 1,6 \\
\hline 4 & Pendidikan & & \\
& a. D3 & 58 & 92,1 \\
& b. S1 & 4 & 6,3 \\
& c. S2 & 1 & 1,6 \\
\hline
\end{tabular}

Berdasarkan tabel 1 diatas diketahui bahwa responden dalam penelitian ini sebagian besar adalah perempuan $(79,4 \%)$ dengan rentang umur sebagian besar $(61,9 \%)$ berumur 26 - 35 tahun dengan lama kerja sebagian besar 1-5 tahun (81 \%). Responden yang berpatisipasi dalam penelitian ini sebagian besar lulusan Diploma III Keperawatan yaitu sebesar 92,1 $\%$.

\section{Pelaksanaan Indikator Mutu}

Gambaran pelaksanaan Indikator Mutu Syariah di Rumah Sakit Islam Yogyakarta PDHI adalah sebagai berikut :

Tabel 2

Analisa Frekuensi Pelaksanaan Indikator Mutu Syariah

\begin{tabular}{cccc}
\hline \multirow{2}{*}{ No } & $\begin{array}{c}\text { Pelaksanaan Indikator Mutu } \\
\text { Syariah }\end{array}$ & $\mathrm{f}$ & $\%$ \\
\hline 1 & Kurang & 4 & 6,3 \\
2 & Cukup & 24 & 38,1 \\
3 & Baik & 35 & 55,6 \\
\hline & Jumlah & 63 & 100 \\
\hline
\end{tabular}

Dari table 2 dapat dikatakan pelaksanaan indikator mutu Syariah oleh perawat sebagian besar dalam kategori baik yaitu sebesar 55,6 \% dan hanya 6,3\% saja yang masuk dalam kategori kurang.

\section{PEMBAHASAN}

\section{Karakteristik Responden}

Berdasarkan tabel 1 diatas diketahui bahwa responden dalam penelitian ini sebagian besar adalah perempuan $(79,4 \%)$. Perbedaan jumlah perawat tersebut dipengaruhi oleh jumlah perawat yang mendaftar di Rumah Sakit Islam Yogyakarta PDHI yang didominasi oleh perawat perempuan. Penelitian (Arini, Mulyono, \& Susilowati, 2015) menyatakan dalam dunia keperawatan sangat identik dengan pekerjaan seorang perempuan, meskipun banyak laki-laki yang menjadi perawat namun proporsi perempuan dalam dunia keperawatan masih mendominasi. Perbedaan peran gender secara sosial akan melahirkan perbedaan peran antara lakilaki dan perempuan (Puspitawati, 2013). 
Rentang umur antara 26 - 35 tahun sebesar 61,9\%. Kebijakan di Rumah Sakit Islam Yogyakarta PDHI mengatur batasan umur perawat yang melamar bekerja adalah maksimal di umur 35 tahun. Hal ini membuat sebagian besar perawat yang bekerja di Rumah Sakit Islam Yogyakarta PDHI berumur di bawah 35 tahun. Rentang umur tersebut menunjukkan masa produktif dalam fase kehidupan manusia. Penelitian Yanti \& Warsito (2013) menyatakan umur dewasa muda pada umumnya perawat masih kurang memiliki tanggung jawab, kurang disiplin, sering berpindah-pindah pekerjaan, belum mampu menunjukkan kematangan jiwa dan belum mampu berpikir secara rasional sehingga perawat di umur dewasa muda masih perlu memerlukan arahan dan bimbingan dalam melaksanakan tugas dan perannya.

Pada penelitian ini lama kerja responden sebagian besar adalah 1-5 tahun yaitu sebesar 81 \%. Hal ini terjadi karena angka retensi perawat yang bekerja di Rumah Sakit Islam Yogyakarta PDHI masih cukup tinggi. Hampir tiap tahun rata-rata ada 1- 2 perawat yang keluar bekerja dari rumah sakit dengan berbagai faktor yang mempengaruhi. Hal ini secara tidak langsung mempengaruhi lama kerja perawat yang ada di Rumah Sakit Islam Yogyakarta PDHI. Pada penelitiannya Yanti \& Warsito (2013) menyampaikan analisisnya bahwa masa kerja perawat yang belum lama akan menyebabkan tuntutan pemenuhan kebutuhan masih kurang hal ini dikarenakan perawat dengan masa kerja yang pendek belum mempunyai tuntutan kebutuhan yang tinggi.

Responden yang berpatisipasi dalam penelitian ini sebagian besar lulusan Diploma III Keperawatan yaitu sebesar 92,1 \%. Hal ini dipengaruhi oleh kebijakan dari Rumah Sakit Islam Yogyakarta PDHI terkait penerimaan perawat baru yang melamar di rumah sakit. Rumah Sakit Islam Yogyakarta PDHI menentukan persyaratan bagi perawat yang bekerja di rumah sakit minimal adalah Pendidikan Diploma III
Keperawatan, sehingga sebagian besar pendidikan perawat yang bekerja di Rumah Sakit Islam Yogyakarta PDHI adalah Diploma III Keperawatan. Pendidikan tinggi minimal pendidikan diploma diharapkan dapat menunjang pelaksanaan kegiatan indikator mutu Syariah karena pada jenjang diploma keperawatan seorang perawat sudah mendapatkan pengetahuan terkait kebutuhan dasar manusia yang mencakup bio psiko sosio spiritual. Pendidikan merupakan kegiatan pembelajaran untuk mengembangkan atau meningkatkan kemampuan tertentu. Tingkat Pendidikan turut menentukan seseorang dalam menyerap dan memahami pengetahuan yang diperoleh, pada umumnya semakin tinggi Pendidikan seseorang semakin baik pula pengetahuannya (Notoatmodjo, 2007).

\section{Gambaran Pelaksanaan Indikator Mutu Syariah}

Dari tabel 2 dapat dikatakan pelaksanaan indikator mutu Syariah oleh perawat sebagian besar dalam kategori baik yaitu sebesar 55,6 \% dan hanya 6,3 \% saja yang masuk dalam kategori kurang. Pelaksanaan indikator mutu Syariah oleh perawat menunjukkan masih adanya pelaksanaan yang kurang baik yaitu sebesar 4 responden $(6,3 \%)$. Keempat responden menyatakan dari 11 indikator mutu Syariah yang dilaksanakan dan ada 5 indikator yang tidak pernah dilaksanakan diantaranya pemeriksaan EKG sesuai gender, pemasangan DC sesuai gender, pemakaian hijab ibu menyusui, pemakaian hijab di kamar operasi dan edukasi Islami. Beberapa faktor dapat menjadi kendala dalam pelaksanaan indikator mutu dalam pelayanan kesehatan. Pelatihan yang berkualitas bagi tenaga kesehatan dalam menerapkan indikator merupakan salah satu hal yang diperlukan untuk meningkatkan kualitas pelayanan (Leemans et al., 2015).

Pada tindakan pemasangan EKG dapat meminta bantuan bangsal lain dalam pelaksanaan tindakan karena adanya 
bangsal yang tidak memiliki perawat lakilaki di ruangannya maupun saat ada tindakan EKG tidak ada perawat laki-laki yang jaga. Hal ini terjadi karena adanya keterbatasan dalam jumlah SDM perawat laki-laki di rumah sakit. Pelaksanaan indikator pemeriksaan EKG sesuai gender mencakup semua golongan pasien termasuk anak-anak. Perawat berkomitmen untuk menjaga aurat pasien yang dirawat dengan memperhatikan pelaksanaan tindakan keperawatan yang melibatkan organ vital. Pernyataan penelitian selanjutnya mengenai pemasangan DC yaitu tentang meminta bantuan bangsal lain apabila ada pasien perlu dipasang DC. Beberapa responden menyampaikan tidak pernah meminta bantuan bangsal lain dalam pemasangan DC. Hasil penelitian menunjukkan sebagian responden sering melakukan edukasi islami pada pasien rawat inap yaitu sebesar 58,7 \%, hasil ini menunjukkan indikator edukasi islami dalam kategori cukup baik sedangkan responden yang selalu melakukan edukasi sebanyak $27 \%$. Hal ini sejalan dengan penelitian yang dilakukan oleH (Ristianingsih, D. Septiwi C, and Yanuar I, 2014) yang menyatakan bahwa perawat di ICU hanya melakukan tindakan keperawatan spiritual yang ringan saja seperti mengingatkan sholat dan menganjurkan berdoa. Faktor ini disebabkan karena belum adanya sosialisasi yang jelas mengenai uraian yang wajib dilaksanakan oleh perawat selain itu rumah sakit juga sudah memiliki Lembaga khusus yang menangani bimbingan rohani pasien. Hasil penelitian lain disampaikan oleh Sari, Abdurrouf, \& Rismawati (2018) menunjukkan bahwa pelayanan keperawatan berbasis syariah di Rumah SakitIslam Sultan Agung Semarang dalam kategori baik. Hal ini akan berpengaruh terhadap tingkat loyalitas pasien, karena ketika pelayanan yang diberikan baik maka pasien akan merasa puas dan nyaman sehingga menimbulkan sikap yang loyalitas.

Materi edukasi islami yang bisa disampaikan oleh perawat kepada pasien adalah mengenai hijab, sholat, tayamum, berdoa, tentang talqin, tentang kesabaran dalam menghadapi ujian sakit seperti yang didapatkan dalam mandatory training. Penelitian dari Suratih, Suranah, \& Riyanto (2014) menyatakan adanya perbedaan kualitas hidup klien yang tidak dan yang diberikan bimbingan spiritual islam. Oleh karena itu bimbingan spiritual yang diberikan kepada pasien dapat menimbulkan rasa nyaman dan tenang bagi pasien dalam menghadapi sakitnya. Menurut Direktur Rumah Sakit Islam Ibnu Sina Makassar dalam penelitiannya Hafid (2016) mengatakan pelayanan seperti dakwah dan bimbingan spiritual harus diberikan kepada pasien dan petugas RS Ibnu Sina guna untuk meningkatkan kesejahteraan petugas serta pasiennya. Menurut Sunawi (2012) Sunawi karakter rabbaniyah atau suatu keyakinan dan penyerahan segala sesuatunya hanya kepada Allah SWT merupakan salah satu karakkteristik untuk membedakan antara pelayanan rumah sakit Islam dengan rumah sakit yang non Islam. Sedangkan untuk orientasi setiap pelayanan, rumah sakit non Islam juga tetap menggunakan unsur seperti karakter akhlaqiyah, waqi'iyah, dan insaniyah, akan tetapi dalam pengelolaannya tetap ada perbedaan dari segi cara penerapan dan cakupan pengembangannya.

Penelitian menurut Irfan (2017) menyatakan dalam proses bimbingan rohani islami ada 5 indikator dari efektivitas komunikasi interpersonal yaitu keterbukaan, empati, sikap suportif, sikap positif dan kesetaraan. Kelima indikator ini apabila dijalankan dalam proses bimbingan maupun edukasi dalam hal pelayanan islami akan menimbulkan hasil yang cukup efektif. Namun ditemukan pula faktor penghambat pelayanan edukasi islami ini yaitu hambatan sosiologis dan psikologis. Hambatan sosiologis dapat terjadi karena perbedaan jenjang Pendidikan, situasi sosial, ideologi, budaya, gaya hidup, norma dan kebiasaan. Hambatan psikologis disini terjadi dari factor pasien sendiri dimana 
pasien sedang sedih, bingung, marah bahkan adanya prasangka pasien pada perawat maupun pemberi informasi yang lain.

Pemakaian hijab ibu menyusui menunjukkan indikator ini kurang baik. Pelaksanaan edukasi hijab menyusui belum membudaya. Hal ini dapat disebabkan karena kuesioner disebarkan secara merata ke 7 bangsal rawat inap dengan pernyataan kuesioner yang sama, sedangkan dalam kenyataannya di rumah sakit bangsal yang memiliki pasien yang menyusui hanya ada 3 bangsal saja sehingga sebagian besar responden tidak pernah menyiapkan, mengedukasi maupun melakukan pemakaian hijab menyusui pada pasien.

Pemakaian hijab di kamar operasi menunjukkan cukup baik. Keberhasilan pelaksanaan indikator ini dipengaruhi dari sosialisasi yang sudah berjalan dan dilaksanakan oleh perawat bangsal. Adanya penyediaan fasilitas untuk mendukung indikator ini seperti baju operasi pasien perempuan yang sudah dilengkapi satu set dengan jilbabnya maupun fasilitas untuk monitoring pelaksanaan indikator berupa stempel pelaksanaan pemakaian hijab saat pasien akan dioperasi. Baju operasi yang disediakan oleh Rumah Sakit Islam Yogyakarta PDHI merupakan baju dengan model baju kurung dengan ukuran besar, longgar, tebal/ tidak transaparan dan sudah dilengkapi dengan jilbab. Komitmen organisasi, kompensasi, dan budaya merupakan salah satu hal yang penting untuk keberhasilan implementasi indicator mutu di pelayanan kesehatan. Penggunaan indikator yang sesuai merupakan salah satu upaya yang dapat dilakukan oleh pelayanan kesehatan sehingga akan berdampak pada efektivitas peningkatan kualitas pelayanan (Utama, 2017).

Hasil penelitian menunjukkan pelaksanaan indikator mutu Syariah di Rumah Sakit Islam Yogyakarta PDHI rata-rata masih kurang baik. Hal ini dapat terjadi karena beberapa indikator mutu Syariah hanya dapat dinilai dari beberapa ruang saja seperti indikator hijab untuk ibu menyusui yang tidak semua ruangan dapat melaksanakan indikator ini.

Sumber Daya Manusia sebagai bagian dari keberhasilan dari tercapainya kualitas mutu pelayanan di Rumah Sakit. Strategi rekruitmen tenaga kesehatan merupakan salah satu upaya yang dapat dilakukan untuk dapat mencapai kualitas pelayanan optimal. Salah satu upaya mengoptimalkan pelayanan dimulai dengan mengaharuskan tenaga kesehatan untuk memakai pakaian yang menutup aurat sesuai dengan prinsip kompetensi tenaga kesehatan. Kemampuan membaca Alqur'ān, pendidikan al-Islam, wawancara syariah, dan tes mental merupakan beberapa hal yang harus dikuasai oleh tenaga kesehatan. Pendidikan dan pelatihan bersifat moral dan spiritual, seperti pelatihan memandikan jenazah, melatih perawat dalam moral kharimah, melatih mereka untuk menumbuhkan salam, Basmalah dan Hamdalah kapan memeriksa pasien, bersikap sopan dan ramah, dapat dipercaya, dan jujur serta benar dalam memberikan layanan kepada pasien sabar. Hal tersebut meruapakan upaya yang dapat dilakukan oleh tatanan pelayanan yang dijadikan dasar untuk mengoptimalkan pelaksanaan indikator mutu Rumah Sakit (Zainuddin, Nasution \& Siregar, 2018).

Berkaitan dengan penelitian diatas maka penelitian selanjutnya perlu mengkaji lebih lanjut tentang faktor-faktor yang dapat mempengaruhi pelaksanaan indikator mutu Syariah. Selain itu, pelaksanaan indikator mutu dapat berjalan dengan lancar juga dipengaruhi oleh standar pelayanan yang operasional. Pelayanan yang operasional berhubungan positif dengan kualitas pelayanan. Pelayanan yang memiliki standar yang operasional dan dikuasi oleh tenaga kesehatan dalam pelayanan kesehatan akan memberikan pengaruh besar dalam pemberian pelayanan kepada pasien dan keluarga (Chahal, 2008). 


\section{SIMPULAN}

Pelaksanaan indikator mutu syariah oleh perawat di Rumah Sakit Islam Yogyakarta PDHI menunjukkan hasil yang baik. Indikator mutu Syariah yang dilaksanakan dengan kurang baik antara lain hijab untuk pasien, mandatory training untuk fiqih pasien, edukasi islami, pemakaian hijab ibu menyusui, pasien sakaratul maut terdampingi denagn talqin, mengingatkan waktu sholat. Indikator mutu Syariah yang termasuk dalam kategori cukup baik antara lain pemasangan EKG sesuai gender, pemakaian hijab di kamar operasi, penjadwalan operasi elektif tidak terbentur waktu sholat, pemasangan DC sesuai gender dan indikator mutu Syariah yang termasuk dalam kategori baik adalah membaca basmalah sebelum minum obat dan tindakan. Monitoring dan system evaluasi yang tepat dapat menjadi salah satu upaya untuk meningkatakan penerapan indikator mutu syariah yang Islami dan berkarakter sehingga dapat meningkatakan kepuasan pasien.

\section{REFERENSI}

Arini, H., Mulyono, W., \& Susilowati, I. (n.d.). Hubungan Spiritualitas Perawat dan Kompetensi Asuhan Spiritual. 425-428.

Dewan Syariah Nasional. (2016). Fatwa DSN MUI No: 107/DSN-MUI/X/2016 tentang Pedoman Penyelenggaraan Rumah sakit Berdasarkan prinsip Syariah. Jakarta: Majelis Ulama Indonesia.

Fuad. (2017). Pengaruh Pelayanan Islami Terhadap Kepuasan Pasien Di Rumah Sakit Umum Daerah (RSUD) Meuraxa Kota Banda Aceh. Universitas Islam Negeri Ar-Raniry.

Hafid, H. (2016). Pengaruh Pelayanan Dengan Prinsip-Prinsip Syariah Terhadap Kepuasan Pasien Pada RS Ibnu Sina Makassaritle. Universitas Islam Negeri Alauddin.

Lamsudin. (2012). Nuansa Pelayanan Kesehatan yang Islami di Rumah Sakit Islam. Suara Muhammadiah, edisi 20-02, hal 1. Suara Muhammadiyah, p. Edisi 20-02 hal. 1.
Mukisi. (2017). Pedoman Standar Pelayanan Minimal RS Syariah dan Indikator Mutu Wajib Syariah. Jakarta.

Mulyadi, D. and, \& Ningsih, F. (2013). Jurnal Manajemen Vol.10 No.3 April 20131203. Jurnal Manajemen Vol.10 No.3 April 2013, 10(3), 1203-1219.

Mustiana, W. (2014). Pengelolaan Dakwah Di Rumah Sakit Islam Pati Tahun 2013-2014.

Notoatmodjo, S. (2007). Notoatmodjo, S. 2007. Promosi Kesehatan dan Ilmu Perilaku. Jakarta: Rinek Cipta.

Nursalam. (2015). Manajemen Keperawatan Aplikasi dalam Praktik Keperawatan Profesional. Jakarta: Salemba Medika.

Puspitawati, H. (2013). Konsep, Teori dan Analisis Gender. Gender dan Keluarga: Konsep dan Realita di Indonesia. Bogor: PT IPB Press.

Ristianingsih, D. Septiwi C, I. Y. (2014). Jurnal Ilmiah Kesehatan Keperawatan, Volume 10, No 2. Juni 2014. Kesehatan, 10(2), 100-107.

Sjarqiah, U. (2015). Fungsi Sosial Rumah Sakit Islam. Suara Muhammadiyah, p. 39.

Solihudin, E. (2012). Membangun Budaya Organisasi RSIJ.

Sumadi, S. (2017). Peran Manajemen Syariah Terhadap Peningkatan Kepuasan Pelanggan Pada Rumah Sakit Islam Di Kota Surakarta. Jurnal Ilmiah Ekonomi Islam, 3(2), 112. https://doi.org/10.29040/jiei.v3i2.104

Sunawi. (2012). Konsep Pelayanan Kesehatan Islami Di Rumah Sakit (Tinjauan Aplikasi Di Rumah Sakit Islam Surakarta).

Suratih, K., Suranah, \& Riyanto. (2014). the Effect of Islamic Spiritual Guidance on Quality of Life in Hemodialysis Patients Hemodialysis Unit Hospital. 82-86.

Yanti, R. I., \& Warsito, B. E. (2013). Hubungan Karakteristik Perawat, Motivasi dan Supervisi Dengan Kualitas Dokumentasi Proses Asuhan Keperawatan. Jurnal Managemen Keperawatan, 1, No. 2, 107-114. https://doi.org/10.1117/12.764094 